\title{
The Origin of the Latin Fifth Declension
}

\author{
Krzysztof Tomasz Witczak
}

University of Lodz, Faculty of Philology,

Chair of Classical Philology, Department of Latin Studies and Linguistics,

171/173, ul. Pomorska, Łódź, 90-236, Polska - Poland; krzysztof.witczak@uni.lodz.pl

For citation: Krzysztof Tomasz Witczak. The Origin of the Latin Fifth Declension. Philologia Classica 2021, 16 (2), 262-276. https://doi.org/10.21638/spbu20.2021.208

The goal of the article is to review Dariusz R.Piwowarczyk's recent works $(2016 ; 2017$; 2017 [bis]; 2019) on the origin of the Latin fifth declension, as well as to demonstrate the correctness of the dual explanation (Witczak 2015) not discussed or even mentioned by Piwowarczyk. The author is convinced that Latin, like other Indo-European languages, once had a separate dual number which disappeared in the pre-literary period. The loss of the dual number disturbed the declension system existing at the time and caused the need for the creation of a new declension class (the fifth declension). The laryngeal phoneme ${ }^{*} h_{1}$ formed the basic dual ending in the Indo-European languages. Proto-Indo-European animate nouns of consonant stems created a strong form in the dual number, demonstrating the ending ${ }^{*}-e h_{1}$ (hence IE. ${ }^{*}-\bar{e}$ and Latin ${ }^{*}-\bar{e}-$ ), whereas inanimate nouns had a weak form (PIE. ${ }^{*}-i h_{1}$, hence Lat. $-\bar{\imath}$ in $v \bar{i} g i n t \bar{\imath}$ 'twenty' and the oblique stem ${ }^{\star}-i \bar{e}-$, attested in Lat. aciēs, mäteriēs etc.). Proto-Latin dual forms ending in ${ }^{*}-\bar{e}\left(<\mathrm{PIE}\right.$. $\left.{ }^{*}-e h_{1}\right)$ referring to animate nouns, as well as dual forms ending in ${ }^{*}-\bar{l}\left(<\right.$ PIE. $\left.{ }^{*}-i h_{1}\right)$ referring to inanimate nouns, underwent the process of collectivization and singularization: most of them gained the status of typical singularia tantum and then formed a separate class of nouns which had $-\bar{e}-$ as the common feature. It is finally suggested that a large group of originally dual nouns (especially the so-called dualia tantum) formed the Latin fifth declension.

Keywords: dual number, dualia tantum, etymology, fifth Latin declension, Indo-European languages, Latin morphology, singularia tantum.

\section{Views on the origin of the Latin fifth declension as documented in relevant literature}

The fifth declension is commonly believed to be a Latin (or possibly Italic) innovation, the origin of which is unclear (Leumann 1977, 285; Beekes 1985, 37-38; Pultrová $2011,99)$. The question of the origin of this inflectional class was recently discussed by Dariusz R. Piwowarczyk (2016, 108-123; 2017, 511-523; 2017 [bis], 247-263; 2019), who reviews the most important opinions on the matter presented over the years. It is worth recalling the basic concepts about the origin of the Latin fifth declension.

Holger Pedersen $(1926,14-18)$ recognized the Latin fifth declension to be an Indo-European archaism. He linked it to the Baltic nominal stems ending in $-\bar{e}$ and on this basis he assumed the existence of Indo-European stems ending in ${ }^{*}-\bar{e}$ and ${ }^{*}-i \bar{e}$. Pedersen's proposal was criticized by Christian Stang $(1966,201)$, who convincingly argued that the majority of the Baltic $\bar{e}$-stems represent the descendants of Indo-European stems with the suffix ${ }^{*}$-iīa $\left(<\right.$ PIE. ${ }^{*}$-iieh $\left.h_{2}\right)$.

(C) St. Petersburg State University, 2021 
Steinbauer (apud Mayrhofer 1986, 133-134), in turn, explained the Latin fifth declension as an offshoot of Indo-European stems in ${ }^{*}-i \bar{a}\left(<\right.$ PIE. $\left.{ }^{*}-i e h_{2}\right)$. He provides a fairly large set of Latin forms ending in -iēs/-ia such as luxuriēs/luxuria as well as correspondences such as that between the Lat. aciēs f. and Proto-Germanic ${ }^{*}$ agjo (cf. OSax. eggja, OHG. ekka, G. Ecke f. 'corner, edge' < PIE. ${ }^{\star} h_{2} e k$ 'ieh $h_{2}$ ). In Steinbauer's opinion, an archaic type of declension was inherited by Latin in which the nominative form (with a lengthened grade) was ${ }^{*}-i \bar{e} s\left(<\right.$ PIE. $\left.{ }^{*}-i \bar{e} h_{2}-s\right)$, and the accusative sg. had the ending ${ }^{*}-i \bar{a} m$ $\left(<\right.$ PIE. $\left.{ }^{\star}-i e h_{2}-m\right)$. This declensional type had allegedly produced the numerous variant forms like mäteriēs vs. māteria.

Peter Schrijver assumed (without much support) that Proto-Indo-European had deverbal abstract nouns ending in ${ }^{*}-i \bar{e} s$ (< PIE. ${ }^{*}$-ieh $1^{-}$, taken from oblique cases of the alleged ${ }^{*} i_{1}$-stems) like the Vedic śámī f. 'work', śaci- f. 'power', as well as denominal abstract nouns with a similar paradigm ${ }^{*}-\bar{\imath}\left(<\right.$ PIE. $\left.{ }^{*}-i h_{2}\right)$ such as the Old Indic $v r k \bar{i}-f$. 'she-wolf' (Schrijver 1991, 383). The Dutch scholar assumed here that Proto-Italic ${ }^{*}$-ie- was generalized to nom.sg. from oblique cases such as gen.sg. where $-i \bar{e}-<^{*} i e h_{1^{-}}$. The suggested phonological development is, of course, acceptable, but the existence of ${ }^{*}{ }^{i} h_{1}$-stem abstract nouns in the Indo-European languages hangs in the air. Most Indo-Europeanists assume that all Indo-Aryan $\bar{i}$-stems reflect the Proto-Indo-European feminine ${ }^{*} i h_{2}$-stems. In other words, his explanation accounts for neither the origin of the Latin fifth declension nor for the numerous variants like mäteria mäteriēs.

Gert Klingenschmitt (1992, 127-135) simplified Schrijver's hypothesis because he assumed the existence of only one feminine suffix ${ }^{*}-i h_{2}$, forming deverbal and denominal abstract nouns, and he explained the unusual phonological development (allegedly based on the acc. sg. ${ }^{*}$-ih $m>{ }^{*}$-iim $>{ }^{*}$-iem) as an analogy to the inflection vulpess:vulpem. In Klingenschmitt's framework, the Latin vulpēs-type goes back to a hysterokinetic $i$-stem inflection, demonstrating the lengthened-grade nominative-accusative in ${ }^{*}-\bar{e} i$ - and $i$-stem in oblique cases, cf. Ved. sákhā- m./f. 'friend, (female) companion', acc. sg. sákhāyam, nom. pl. sakhấyah, dat. pl. sákhibhyah. It should be emphasized, however, that all inherited words such as Lat. vulpess (gen. sg. vulpis) were included in the third declension (not in the Latin fifth declension). Moreover, the Latin word socius m. 'fellow, partner, comrade, companion', related etymologically to Vedic sákhā-, was remodelled to resemble $o$-stems (the second declension).

The current state of research on the origin of the Latin fifth declension is summarised by Lucie Pultrová $(2011,99)$ :

"The $5^{\text {th }}$ declension as a whole (leaving aside the root nouns diēs and $r \bar{e} s$ ) is problematic as to origin, the endings are to a considerable extent analogical and above all, it is not clear how to interpret the suffix - $\bar{e}-$ - did it also originate as late as in Latin, or is it inherited?"

Krzysztof Tomasz Witczak $(2015,101-120)$ refers to Beekes's opinion, according to which "the $\bar{e}$-stems of the Latin fifth declension had $-h_{1}$ in the nominative" (Beekes 1985, 37). He explains the Latin $\bar{e}$-stem as a trace of the dual morpheme ${ }^{\star} h_{1}$, stressing that so far nobody has attempted to provide an explanation of the appearance of the Latin fifth declension ( $\bar{e}$-stems) as a result of the loss of the Indo-European dual inflection, whose main feature was the suffix ${ }^{*}$-eh $h_{1}$ (or simply $\left.{ }^{*} h_{1}\right)$ for animate nouns and its variant ${ }^{*}-i h_{1}$ for the neuter gender and sometimes for the feminine (originally for inanimate nouns). He strongly stresses that the historical development of Latin words ending in $-\bar{e} s\left(<{ }^{*}-e h_{1}-s \leftarrow\right.$ the dual suffix $\left.{ }^{*}-e h_{1} \sim^{*}-h_{1}\right)$ and $-i \bar{e} s\left(<{ }^{*}\right.$-ieh $h_{1}-s \leftarrow$ the dual suffix ${ }^{*}-i h_{1}$, oblique cases $\left.{ }^{*}-i e h_{1-}\right)$ 
is fully credible phonologically. In his opinion, the erstwhile dual character of some Latin $\bar{e}$-stem nouns can be demonstrated on the basis of their probable semantic development.

Dariusz R. Piwowarczyk discusses the problem of the origin of the fifth Latin declension in his recent book (2019), as well as in his three earlier articles (Piwowarczyk 2016, 118; 2017, 511-523; 2017 [bis], 247-263). He notices weak points in the argumentation of his predecessors, omitting the new interpretation, according to which the Latin fifth declension was created on the basis of the lost dual forms (Witczak 2015). ${ }^{1}$ Generally, he follows Klingenschmitt's position, the alleged model for the analogy being the inflection diēs, abl. sg. diēd, acc. sg. diem (with a reference to Late IE. ${ }^{\star}$ dièm acc. sg., originally PIE. * dieum). It is hardly convincing that one word and only one case (accusative sg.) could have been a model for the creation of the fifth declension.

In this work, I would like to review arguments of the relevant researchers and demonstrate the correctness of the hypothesis, according to which the Latin fifth declension should be explained as an innovation created on the basis of lost nouns used originally in the dual.

\section{Common features of the Latin fifth declension}

In his book Piwowarczyk $(2019,15-18)$ summarizes the following typical features of the Latin (and Italic) fifth declension:

2.1. The common feature of the fifth declension is the $\bar{e}$-stem, which - in his opinion - can hardly represent an Indo-European heritage.

2.2. Most nouns demonstrate no traces of the plural forms and belong to the so-called singularia tantum.

2.3. A full paradigm is only attested for two Latin nouns: diēs 'day' and rēes 'thing'.

2.4. Most nouns of $\bar{e}$-stem represent abstract formations.

2.5. Numerous abstract nouns in -iēs demonstrate a variant form in -ia.

2.6. Extra-Latin (Sabellic) reflexes of $\bar{e}$-stem are scarce and uncertain.

The standard paradigm of the Latin (and Italic) fifth declension is presented in Table.

Table. The declension of Latin diēs, rēs and Umbrian iovies

\begin{tabular}{|c|c|c|}
\hline Case and number & Latin & Sabellic (esp. Umbrian) \\
\hline nominative / vocative sg. & diēs 'day', rēs 'thing' & $\begin{array}{l}\text { ? Umbrian di voc. sg. 'Iuppiter' (if from *diiē voc. } \\
\text { sg., cf. Lat. diēs 'day') }\end{array}$ \\
\hline genitive sg. & diēì (also diei, diē̄), rē̄i & Umbrian ri 'rei' \\
\hline dative sg. & diēè (also diēe, diei), rēē & \\
\hline accusative sg. & diem, rem & $\begin{array}{l}\text { ? Umbrian dei 'Iovem' (if from }{ }^{*} \text { diiēm acc. sg., cf. } \\
\text { Lat. diem acc. sg. 'day') }\end{array}$ \\
\hline ablative sg. & $d i \bar{e}, r \bar{e}$ & Umbrian ri 're' \\
\hline nominative / vocative pl. & diēs, rēs & \\
\hline genitive pl. & diērum, rērum & \\
\hline dative pl. & diēbus, rēbus & Umbrian iovies 'iuvenibus' \\
\hline accusative pl. & diēs, rēs & Umbrian iovie 'iuvenes' \\
\hline ablative pl. & diēbus, rēbus & \\
\hline
\end{tabular}

Source: Author's own work.

${ }^{1}$ Note that the dual hypothesis was mentioned or supported in other articles by the same author (Witczak 2017, 37-58; 2017 [bis], 191-194; 2018, 47-58; 2019, 107-123; 2021, 5-18). 
Below I present the main arguments for the dual origin of the Latin fifth declension and demonstrate that the dual hypothesis provides a much better explanation for the basic features of the paradigm just presented.

\section{The dual number in the Indo-European languages}

The most ancient Indo-European languages (including Ancient Greek and Vedic) have three number categories: the singular, the dual and the plural (Meier-Brügger 2000, 258-259; Clackson 2007, 100-104). The majority of modern languages of the Indo-European family have only two categories: the singular and the plural.

In the Indo-European languages the dual number was typically used for natural pairs

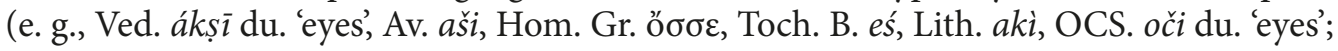
Lith. ranki du. 'hands', Cz. ruce pl. [ $<$ du.] 'hands' < Balto-Slavic ${ }^{\star}$ rankai du. 'two hands'), sometimes also for accidental or artificially arranged pairs (e. g., Hom. Gr. ä $v \delta \rho \varepsilon$ du. 'two men', i $i \pi \omega \mathrm{du}$. 'two horses [pulling one carriage]', Toch. B oksaine du. 'two oxen [in one yoke]'), and possibly also for two objects of the same kind (e. g., Toch. B pwäri du. 'two fires', Lith. dví líepi 'two lime trees'). Occasional elliptical usage of the dual is also attested e. g., Ved. $d y \bar{a} v \bar{a}$ du. 'heaven and earth' (literally 'two heavens'), áhanī du. 'day and night' (lit. 'two days'); Av. pitara du. (= Ved. pitárā) 'father and mother' (lit. 'two fathers'); Toch. B. ñaktene du. 'a god and his wife' (lit. 'two gods'); Hom. Gr. Aïavte 'Ajax and his brother Teucer' (lit. 'two Ajaxes') (Wackernagel 1957, 151; Malzahn 2000, 45-52; Clackson 2007, 101).

The degree of preservation and productivity of the dual in individual Indo-European languages differs considerably (Fritz 2011). All three number categories have been well preserved in the Indo-Iranian group, among others in the Vedic (Malzahn 1999), Avestan and Old Persian languages as well as in the Balto-Slavic group as in Old Lithuanian, some of the modern Lithuanian dialects, Old Church Slavonic and many of the Slavic languages, both historical and contemporary (Dostal 1954; Fritz 2011, 136-154). Other branches of the Indo-European family, e. g., the Germanic, Celtic, or Tocharian languages present a somewhat different state, in which the dual is still functional, but gradually becomes obsolete. A similar stage of gradual loss of the dual number can be observed in Ancient Greek (Hierche 1987; Fero 2013).

Some traces of the former dual remained in the ancient Anatolian languages, cf. Hitt. laplapan n. 'eyelash; hairs on the eyelid', laplapi nom. pl. n. $\left(\leftarrow\right.$ du. with $\left.{ }^{*}-i h_{1}\right)$ 'eyelashes; hairs growing on the upper and lower eyelid'; Hitt. mèni nom.-acc. n. 'face' (originally du. 'two cheeks') vs. Hitt. mēna- n./c. 'cheek', Lat. mentum n. 'chin' (Rieken 1994, 51-53; 1999, 56-57; Kloekhorst 2008, 577). It is also believed that the Hittite word elzi n. 'pair of scales / die beiden Hälften' (<PIE. ${ }^{\star} h_{1}$ elt-i $i h_{1}$ du. n. 'two trays of the scales', cf. OIr. leth 'half', Lat. latus 'side') represents an original dual form (Kloekhorst 2008, 240; Fritz 2011, 185-188).

The dual number has disappeared in most of the languages of the later stages, in many cases leaving more or less numerous traces in the lexicon. It must be noted though that even in modern times there are languages with a fully productive grammatical category of the dual, including Upper and Lower Sorbian as well as Slovenian (Tjasa 2008). 


\section{Traces of the dual number in Latin}

The dual number as a separate category was presumably lost in Latin and other Italic languages already in the prehistoric period (Buck 1933[2009], 171). It is commonly believed that Latin kept relatively few traces of the dual (Sihler 1995, 245-246; Weiss 2009, 195), mostly in the numerals, cf.

4.1. Lat. duo 'two' < IE. *duwō < PIE. * duwo- $h_{1}$ (Pokorny 1959, 228-232; Blažek 1999, 163-184; Meiser 2010, 170).

4.2. Lat. oktō 'eight' < IE. ${ }^{*}$ oḱtō ' 8 ' < PIE. ${ }^{\star} h_{3}$ ekto- $h_{1}$ (cf. Pokorny 1959, 775; Blažek 1999, 263-276; Meiser 2010, 170).

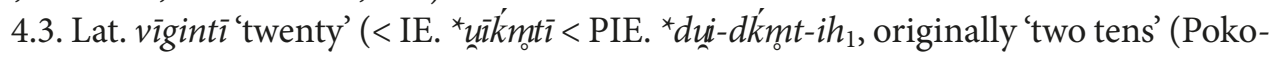
rny 1959, 1177; Sihler 1995, 420, 422).

Two Latin forms ambō, ambae, ambo 'both' and duo, duae, duo 'two' have specific inflection which may be a result of the transformation of the original dualia tantum within the first and second declension. Their inflection keeps the original dual endings only in the nominative, but it does not demonstrate the dual endings in the remaining cases, the actual ones are regular plural endings (e. g., gen. pl. ambōrum, ambārum, ambōrum). This is thus a case of an adaptation and substitution where the older dual inflection is replaced with the plural. In other words, numerous Proto-Indo-European dualia tantum became the Latin pluralia tantum.

In general, one can agree that the traces of the dual number in Classical Latin are few in number and are mostly restricted to ambō 'both' (Mańczak 1991, 179-186) and the numerals $(d u \bar{o}, o c t \bar{o}, v \bar{i} g i n t \bar{\imath})$ (Weiss 2009, 195). The question of the preservation of the dual number in the nominal forms of Early Latin is debatable (Witczak 2017; 2019).

\section{Dual endings in the Indo-European languages}

It is assumed that in the Proto-Indo-European language the laryngeal ${ }^{\star} h_{1}$ formed the basic dual ending, which could have a strong form (PIE. ${ }^{*}-e h_{1}$ or alternatively PIE. ${ }^{*}-h_{1} e$ $\left./{ }^{*}-h_{1}\right)$ in animate nouns, or a weak form with a preceding vocalic element ${ }^{*}-i$ - (PIE. ${ }^{*}-i h_{1}$ ) in inanimate nouns (Beekes 2011, 216-217). ${ }^{2}$ It is assumed that the numeral 'two' originally had two alternative forms: PIE. ${ }^{*} d u w o-e h_{1}$ 'two (persons)' and PIE. ${ }^{*} d u w o-i h_{1}$ 'two (things)', which later developed into the masculine and neuter forms: late IE ${ }^{\star} d u w \bar{o} \mathrm{~m}$. 'two' (whence e. g., Gr. $\delta \dot{v} \omega$ m., f., OInd. $d(u) v \bar{a}$ m., Av. duvā m., Lat. duo m., OCS. dźva m., Toch. A wu) and *duwoi n. 'two' (whence e. g., Ved. duvé n., Av. baē n., OCS. drvě n., Toch. A we, B wi). The feminine gender, which most likely developed after the loss of the category of animacy, found still in the Anatolian languages, had the weak ending ${ }^{*}-i h_{1}$, typical of inanimate nouns. The numeral 'two' thus had the feminine form IE. ${ }^{*} d u w \bar{a} i$ ' two' (< PIE. $\left.{ }^{\star} d u w e h_{2}-i h_{1}\right)$, cf. Ved. duvé, dvé f., Av. baē f., Lat. duae f., OCS. drvě f., Lith. dvi f. 'two' $\left(<{ }^{\star} d v i e<\right.$ Proto-Baltic $\left.{ }^{\star} d v a i\right)$, OE. twá f. 'two' (< Proto-Germanic ${ }^{\star}$ twai). Only the Greek feminine form $\delta$ v́ $\omega$ was identical to the masculine one.

${ }^{2}$ Kortlandt $(1991,5-8)$ tried to prove that the nominative dual of inanimate nouns was originally ${ }^{*}-i$, but his hypothesis has not been accepted since it is easier to assume that the particle ${ }^{*} i$ was originally an exponent of the inanimateness, and the laryngeal ${ }^{*} h_{1}$ functioned as a general dual marker in both animate and inanimate nouns. 
It is thus no wonder that two ways of forming the dual were available for the Proto-Indo-European appellative ${ }^{*} m_{e} h_{2}$ ter- $\mathrm{f}$. 'mother':

[1] with the Indo-European dual ending ${ }^{*}-\bar{e}\left(<\right.$ PIE. $\left.{ }^{*}-{ }^{*} h_{1}\right)$, e. g., Ved. mātárā du. 'two mothers'

[2] with the Indo-European dual ending ${ }^{*}-\bar{i}\left(<\right.$ PIE. $\left.{ }^{*}-i h_{1}\right)$, e. g., OCS. materi f. du. 'two mothers', Lith. móteri f. du. 'two mothers.'

The last ending, PIE. ${ }^{*}-i h_{1}$, was originally found with inanimate nouns (later neuters) but the feminine forms sometimes took it over as the basic variant. It cannot be excluded that the appellative ${ }^{*}$ meh $_{2}$ ter- had both the meaning of a person ('mother') as well as that of various objects (e. g., 'tree trunk; body of the tree') already in Proto-Indo-European, cf. Lat. mäter f. 'mother' and '(of trees) parent-stock; tree trunk. Thus it cannot be excluded that the Proto-Indo-European word ${ }^{*}$ meh $_{2}$ ter- had created two dual forms in Proto-Latin: ${ }^{*}$ mäterē f. du. 'two mothers' (animate noun) and ${ }^{*}$ mäterī f. du. 'two tree trunks' (inanimate noun). The second (inanimate) variant could be treated as a probable source for Lat. māteriēs f. 'timber, tree trunk; building material, wood; substance, ingredient, element' ${ }^{4}$ (cf. below, 8.5).

As far as consonantal stems are concerned, there was considerable variety and linguists cannot tell which dual ending was once preferred in Latin and other Italic languages. The present author believes that Latin for some time kept the dual ending ${ }^{*}-\bar{e}$ $\left(<\right.$ PIE. $\left.{ }^{*}-e h_{1}\right)$ for animate nouns, which can be observed also in the Indo-Iranian family. ${ }^{5}$ The loss of the dual caused the Archaic Latin forms ending in $-\bar{e}$ (once dual forms) to form a separate group, the fifth declension. Should it be assumed that the Italic languages had a variant with the dual ending ${ }^{*}-\breve{e}\left(<\right.$ PIE. $\left.{ }^{*}-h_{1} e\right)$, this will not change anything here since the long vowel ${ }^{*}-\bar{e}$ - would still have to have been formed in the oblique cases. For instance, the genitive dual ending referring exclusively to inanimate nouns was ${ }^{*}-\bar{e} s$ in Indo-European (earlier PIE. ${ }^{*}-e h_{1}-s$ gen. du.), which is proved by the gen. du. form in Avestan $-\stackrel{\bullet}{ }(<\operatorname{Iran}$. $\left.{ }^{*}-\bar{a} h\right)$. Thus, without doubt the dual inflection with the marker $-\bar{e}-\left(<\right.$ PIE. $\left.{ }^{*}-e h_{1^{-}}\right)$would have ensured the stabilization of the feature $-\bar{e}$ - after the loss of the dual number in the Italic languages.

In the case of the dual forms of the neuter gender (and sometimes feminine as well) ending in ${ }^{*}-\bar{i}\left(<\right.$ PIE. $\left.{ }^{*}-i h_{1}\right)$ the genitive dual was similar, i. e., ${ }^{*}-i \bar{e} s\left(<\right.$ PIE. ${ }^{*}-i e h_{1}-s$ gen. du. of inanimate nouns $)^{6}$. In other words, the forms of the oblique cases gave rise to the ones

${ }^{3}$ It should be noted that Gr. $\mu \eta \dot{\tau} \varepsilon \rho \varepsilon$ du. 'two mothers' demonstrates a different dual ending *-ĕ. It is uncertain whether the dual consonant-stem nouns in Ancient Greek should be treated as an innovation (with a shortened vowel in the final position) or an alternative formation. Theoretically, the Ancient Greek dual ending $-\varepsilon$ could derive from PIE. ${ }^{*}-h_{1} e$ or PIE. $\left.{ }^{*}-h_{0}\right)$.

${ }^{4}$ Following Michiel de Vaan (2008, 367), I believe that Lat. māteriēs derives from Lat. mäter f. 'mother', also 'tree trunk'. I reject Osthoff's ingenious etymology, according to which the Latin words màteria and mäteriēs reflect the Proto-Italic archetypes ${ }^{*} d m a \bar{t} t e r i \bar{a} /{ }^{*} d m \bar{a} t e r i \bar{e} s \mathrm{f}$. 'building material', which go back to the intensive variant ${ }^{*} d m$-eh $h_{2}$ of the Proto-Indo-European root ${ }^{*} d e m$ - 'to build', cf. Gr. $\delta \varepsilon \dot{\mu} \mu \omega$ 'id., perf. med. $\delta \varepsilon \dot{\delta} \mu \eta \mu a \mathrm{l}$, Dor. $\delta \dot{\varepsilon} \delta \mu \bar{\alpha} \mu a \mathrm{l}$ (Beekes 2010, 314-315).

5 There is no clear evidence as to the form of the dual ending of the nominal forms with consonantal stems in the Celtic languages (the group closest to Italic). Indeed, the Old Irish nom.-acc. du. sieir 'two sisters' may be derived from any of the proto-forms: ${ }^{*}$ swesorē (cf. OInd. svasārā du. 'two sisters'), ${ }^{*}$ swesore or ${ }^{*}$ swesori (Adams 1991, 12). The Gaulish noun suiorebe (abl.-soc. du.) 'with two sisters' (Witczak 2015 [bis], 59-62) seems to exclude the third possibility.

6 The lack of comparative evidence for reconstructing the full inflection of inanimate dual forms in ${ }^{*}-i-h_{1}$ should be emphasized here. In fact, the dual inflection in Proto-Indo-European is hardly possible to be reconstructed. Avestan still keeps the genitive dual (Av. $-\bar{a}<$ PIr. ${ }^{*}-\bar{a} h$ seems to derive from Indo-Iranian ${ }^{*}-\bar{a} s$ 
typical of the Latin fifth declension, and the transformation of the old dual inflection ${ }^{{ }^{*}} \bar{i}$ (with ${ }^{*}-i \bar{e}-$ in oblique cases) into the singular paradigm ${ }^{*}-i \bar{e} s,{ }^{*}-i \bar{e} i$ was a perfect basis for the formation of the fifth declension already in the preliterary period.

\section{The cause of the loss of dual number in Latin}

It is most probable that the loss of the dual as a separate category took place within the first declension $(\bar{a}$-stems), and then within the second one (o-stems). In the nominal paradigm, a specifically Latin innovation was introduced already in the preliterary period, causing serious changes in the inflection system. The innovation was the replacement of the old plural endings ${ }^{*}-\bar{a} s$ and ${ }^{*}-\bar{o} s$, which are well attested in the other Italic languages, by the endings of the pronominal system ${ }^{*}-\bar{a} i$ (whence OLat. $-\bar{a} i$ and Lat. $-a e$ ) and ${ }^{{ }^{*}}$-oi (whence OLat. -ei and Lat. $-\bar{\imath}$ ).

The new plural forms with the nom. pl. ending ${ }^{*}-\bar{a} i$ (e. g., Lat. arae, iuvencae versus Osc. aasas pl. 'stakes, altars', Umbr. ivengar pl. 'heifers') proved identical to the dual forms *-äi (cf. Lat. ambae f. 'both', duae f. 'two'). The identity of the dual and the plural nominative forms (as well as some of the oblique case forms probably) in the early phase of Latin (OLat. $-\bar{a} \bar{\imath}$, Lat. $-a e$ represented nom. pl. f. = nom. du. f., cf. duae iuvencae) was a factor strong enough to cause elimination of separate dual forms in the feminine gender.

In the case of the $o$-stems, the nominative dual of the old neuter nouns (nom. du. $\mathrm{n}$. ${ }^{*}$-oi) became identical with the nominative plural of the masculine gender (nom. pl. m. ${ }^{*}$-oi, whence OLat. $-\check{o} i>-e i>$ Lat. $-\bar{\imath}$ ). The dual forms were thus treated as plural ones with some variation in the gender assignment, which was relatively frequent anyway.

The elimination of the dual number in the second declension occurred in two ways: the Romans started to treat the dual neuter form as a plural one and on this basis created new variant forms in the masculine gender as an alternative to the original neuter of the given nouns. I can illustrate this development with the following examples:

6.1. The Latin word frēnum n. 'rein, bridle, harness' has two alternative plural forms: the regular and more common frēna, -örum and the irregular (and relatively rarer) variant frēni, -ōrum. The latter form undoubtedly represents the old dual (Weiss 2009, 195, fn. 9). Reins comprise two ropes or straps that are used to direct the horse, thus the dual form is very natural, unlike the plural one. Yet, the old dual frēni was reinterpreted as a plural form (gen. pl. frēnōrum, dat.-abl. pl. frēnīs etc.).

6.2. Lat. lōrum n. 'strap, girdle, rein' (< PIE. ${ }^{*} l e h_{3}$ som n.) has two alternative plural forms: the regular lōra, -ōrum and the irregular variant lōri, -ōrum. It is probable that Late Latin lōrus (m.) represents an innovative form created on the basis of the irregular plural lōrī, originally nom.-acc. du. n. ${ }^{*} \bar{l} \bar{s} s-\bar{i}$ 'two straps, two reins' (< PIE. $\left.{ }^{*} l e h_{3} s o-i h_{1}\right)$. The loss of the dual number in the early pre-literary phase of the development of the Latin language caused the reinterpretation of the preserved dual forms (Witczak 2017 [bis], 185-196).

\footnotetext{
$<$ PIE. $\left.{ }^{*}-e h_{1} s\right)$ distinct from the locative dual (Av. $-\bar{o}<$ PIr. ${ }^{*}$-auh), while Vedic has only $-o s(<$ Indo-Aryan ${ }^{*}$-aus < PIE. loc. du. $\left.{ }^{*}-e h_{1}-u-s\right)$ for both these cases by a secondary generalization of the dual inflection. In fact, most Indo-European languages demonstrate a simplification of the dual inflection, which consists in the full identification of the gen. du. with the dat. du. and/or loc. du., e. g., Hom. -oüv, Arc. -oovv, Att. -oov (< PGr. ${ }^{*}$-olvv < PIE. loc. du. ${ }^{*}-o-i h_{1}-u$-, created on the basis of the inanimate dual inflection). The Mycenaean ending $-o-j u$ is also extracted as the dative dual ending in several Theban Linear B tablets (Witczak 2011, 62-67). Of course, I agree with one of the peer reviewers that it is extremely difficult to prove whether the Avestan genitive of the dual inflection represents an Iranian innovation or an Indo-European heritage.
} 
6.3. The Latin word oculus $\mathrm{m}$. 'eye' has a regular nominative pl. oculī. Its Indo-European cognates, however, have neuter forms both in the singular (e. g., OCS. oko, Pol. oko n. 'an eye') and the dual (cf. OCS. oči du. 'two eyes', Pol. oczy pl. 'eyes' < PSl. ${ }^{\star}$ oči du. < Late IE. ${ }^{\star} o k^{u} \bar{\imath}$ du. < PIE. ${ }^{\star} h_{3} \mathrm{e}^{u}-i h_{1}$ du. 'two eyes', cf. Hom. Gr. ö $\sigma \sigma \varepsilon$ du. 'two eyes', Lith. aki du. 'id.'). It is very likely that the nom. pl. m. oculi is a diminutive of the nom. du. n. ${ }^{*} o k^{u} \bar{\imath}$ ' two eyes', and the Latins treated the old dual as a masculine plural. On this basis, they formed a new masculine nom. sg. oculus. ${ }^{7}$

6.4. The Latin plural form caeli (m. pl.) is connected with the neuter noun caelum $\mathrm{n}$. 'heaven.' It can be explained as a primitive dual form denoting 'two heavens', i. e., 'daily heaven and nightly heaven.' A similar hypothesis is suggested by Michael Weiss (2017, 661-667): the Latin plural form caeli (originally a neuter thematic dual ending with * ${ }^{*}$ $i h_{1}$ ) was used in an elliptical sense, thus it could refer to heaven and earth, i. e., the two elemental halves of the universe. Weiss additionally argues that the original meaning of Lat. caelum was 'division, part'.

Nominal paradigms of the $i$-stems, $u$-stems as well as consonantal stems most likely kept separate dual forms for longer than the $\bar{a}$-stems and $o$-stems, but one can hypothesize that the elimination of the dual number proceeded fairly quickly. The pluralization of the dual in the first and second declensions ( $\bar{a}$-stems and $o$-stems, respectively) happened largely without problems. A similar process took place in the paradigms of the other stems and usually the pluralization consisted simply in adding a final $-s$.

\section{Dual hypothesis vs. Piwowarczyk's vision and/or different explanations of the origin of the Latin fifth declension}

Having demonstrated the main elements of the dual hypothesis I would like to compare the dual hypothesis with other explanations, including Piwowarczyk's recent solution. My argumentation follows the points introduced with an account of the main features of the Latin fifth declension, as presented in section 2.

7.1. The $\bar{e}$-stem as a common feature of the Latin fifth declension (see 2.1).

The dual hypothesis connects Latin $\bar{e}$-stem nouns with the dual ending ${ }^{\star} h_{1}$, which is reflected in the endings ${ }^{*}-\bar{e}\left(<\right.$ PIE. $\left.{ }^{*}-e h_{1}\right)$ and ${ }^{*}-\bar{i}\left(<\right.$ PIE. $\left.{ }^{*}-i h_{1}\right)$ in all consonantal stems attested in the Indo-European languages. The ending ${ }^{*}-\bar{e}$ referred primitively to animate nouns, whereas the ending ${ }^{*}-\bar{\imath}$ (gen. du. $-i \bar{e} s$ ) created dual nouns of neuter gender (originally nouns with the inanimate meaning).

Piwowarczyk $(2017$ [bis]; 2019, 126) argues that there is no actual evidence for the nominal affixes ${ }^{*}-e h_{1}$ - and ${ }^{*}$-ieh $h_{1}$ in Proto-Indo-European. Unfortunately, he does not take into account that the same or similar affixes (PIE. ${ }^{*}-e h_{1^{-}}$and PIE. ${ }^{\star}-i h_{1^{-}}$) were used to create the dual forms of nominal formations belonging to consonantal stems.

Piwowarczyk tries to explain the alternative $-i \bar{e} s /-i a$ inflection in Latin as a remodeling of the $\bar{i}$-stem declension. The feminine suffix ${ }^{*}-\bar{i}\left(<\right.$ PIE. $\left.{ }^{*}-i h_{2}\right)$ explains Latin formations ending with $-i a$, but Latin formations in -iess cannot derive from the same source.

7.2. Singularia tantum of the fifth declension (see 2.2).

The loss of the dual number in most Indo-European languages did not happen solely via pluralization of old dual forms, but also by way of their singularization (i.e., the

\footnotetext{
7 A hypothesis proposed by A. Nussbaum (see Weiss 2009, 195, fn. 9).
} 
old dual inflection being remodelled as singular with an innovative, frequently abstract meaning). It is highly probable that some Proto-Latin dual forms (especially dualia tantum) could be treated as separate nouns with the singular form and the dual (later plural) meaning, i. e., they had to be used as typical collective (uncountable) nouns. One of the basic features of the collectives consists in an absence of the plural forms. ${ }^{8}$ In other words, the dual hypothesis explains an essential feature of the Latin fifth declension. Alternative suggestions cannot explain why the majority of $\bar{e}$-stem nouns in Latin, except two instances (discussed in 7.3), have no plural forms, thus they represent the singularia tantum.

7.3. Latin diess and rēs (see 2.3). Where did their plural forms derive from? The full paradigm of the fifth declension is only attested for Latin diēs 'day' and rēs 'thing'. Why do these two words demonstrate plural forms? In my opinion, Lat. diēs, -iēi f. 'day' and its Celtic cognates (cf. OIr. die 'day', OW. did 'id., MW. dydd, OBret. ded, Bret. deiz 'id.' < PC. ${ }^{*}$ diii $i \bar{i}$ - or ${ }^{*}$ diu $\left.i \bar{i}-\right)$ derive from the Italo-Celtic archetype ${ }^{*}$ diu $i \bar{e} e s$, which goes back to an elliptic dual *diu-ih $($ ('day and night', literally 'two days'), created on the basis of PIE. *diuóm n. 'clear sky, day' (see 8.3). The Italo-Celtic formation in question lost an elliptic and abstract sense ('day and night; 24 hours' time') and secondarily introduced a singular and concrete meaning ('a day'). This semantic innovation resulted in creation of the plural forms. The Latin word rēs preserved an earlier abstract sense ('reality, truth') and later introduced a secondary concrete meaning ('thing, object, fact'). In other words, the Latin word rēs, as well as diēs, gained the full paradigm thanks to their innovative semantics.

The dual hypothesis easily explains how the plural forms of diēs and rēs (of secondary origin) could be introduced to the Latin fifth declension. No alternative suggestion gives an acceptable solution of the observed phenomenon.

7.4. Abstract formations of the fifth declension (see 2.4). Numerous dual forms, attested in the Indo-European, seem to present an elliptic sense (e. g., Ved. dyấvā du. 'heaven and earth', Av. pitarz du. 'father and mother'), which can easily develop into an abstract and singulative semantics (e. g., 'a specific part of the universe', 'a parent, a patron') after the loss of the dual number as a grammatical category. This is why most nouns belonging to the fifth declension represent abstract formations.

Both Piwowarczyk (2019) and his predecessors provide no explanation for numerous abstracts belonging to the Latin fifth declension.

7.5. Latin variants in -iēs and -ia (see 2.5).

The observed variation seems to be of secondary origin. Below (8.5) it is suggested that two Latin nouns mäteriēs (gen. sg. mäteriēi) f. and mäteria (gen. sg. mäteriae) f. 'timber, tree trunk; building material; substance, ingredient, element' initially were parallel formations, representing two different and originally not synonymous words. Both terms derive from the Latin word mäter f. 'mother, tree trunk' (<PIE. ${ }^{*}$ meh $_{2}$ ter $\mathrm{f}$.). The origin of Lat. mäteria is clear. It represents a collective noun in -ia $\left(<\right.$ PIE. ${ }^{*}$-iieh $\left.h_{2}\right)$, demonstrating the primitive sense 'multiplicity, collectivity of what is specified in the base', i. e., a multiple character of the material. On the other hand, Lat. mäteriès derives from an old dual form

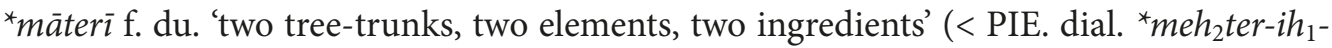
'two mothers', cf. Lith. móteri f. du. 'id.; OCS. materi f. du. 'id.'). The discussed example clearly demonstrates that the Latin formation in -iēs referred to one substance made of

${ }^{8}$ It is worth emphasizing that the "collective nouns (nomina collectiva) when defined from a descriptive point of view are denominal derivatives with a singular form (singularia tantum) demonstrating a collective meaning" (Habrajska, Rychło, Witczak 2020, 262). 
two ingredients, while the variant in -ia referred to the substance made of many elements (see 8.5). Further items in -iēs are discussed below in section 8 .

The dual hypothesis explains the abstract nouns in -ia and -iēs as two parallel and separate formations. The traditional position explains nothing. The new monograph exclusively devoted to this problem (Piwowarczyk 2019) does not contain a convincing solution for the Latin -iés/-ia inflection (see 7.1 and sect. 1).

7.6. The Sabellic reflexes of $\bar{e}$-stem (see 2.6).

According to Piwowarczyk $(2016,116-117 ; 2019,18)$, there is only one independent appellative in -iess in the Sabellic languages, without a parallel Latin formation, namely, Umbrian *iovies f. (acc. pl. iovie, dat. pl. iovies) 'young people, youth' (Untermann 2000, 353), cf. Lat. iuvenis m. f. 'young man, young woman', metonymically also 'youth'. In this case the likely derivational basis could be the dual form ${ }^{*}$ iovi $\bar{i}\left(<\right.$ PIE. ${ }^{*} i e w-i h_{1}-$ nom. du. 'two young people, a young couple; a young pair'). ${ }^{9}$

The Sabellic form in question can easily be explained on the basis of the dual hypothesis. The dual number as a separate category was completely lost in the Italic languages, thus the fifth declension had to be used not only in Latin, but also in most Sabellic languages.

\section{Dual forms of the Lat. vìgintī type}

Piwowarczyk's monograph (2019) is devoted especially to the question of the Latin $-i \bar{e} s /-i a$ inflection. This is why for the purposes of the present article it is necessary to demonstrate that most forms in -iēs should be explained as possible traces of lost dual nouns. I cannot agree with Piwowarczyk that the Latin forms in -iēs, created by analogy to the Latin word diess, represent alternative (secondary) variants of the forms in -ia. It is worth emphasizing that Celtic lexical documents serve as evidence for the dual origin of Lat. diēs 'day' (see 8.3). This observation excludes the traditional hypothesis, supported by Piwowarczyk $(2017,512-515 ; 2019,126)$, according to which the full paradigm of Lat. diēs was secondarily created on the basis of the original accusative sg. diem (as if from IE. ${ }^{*}$ diēm < PIE. ${ }^{*}$ dieum $) .{ }^{10}$

I would like to emphasize here that the Latin cardinal numeral vigintī 'twenty' is commonly believed to be a remnant of the old dual number. It represents the Indo-European

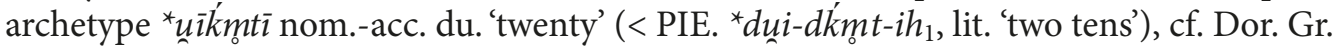

${ }^{9}$ Lat. iuvenis m./f. 'young man, young women', adj. 'young' and Umbr. iovies f. 'young people, youth' is evidently related to Ved. yúvan-adj. 'young', m. 'young man' and Av. yuvan- and yauua- m. 'youth' (de Vaan 2008, 317). In my opinion, it is uncertain whether the Latin and Umbrian words in question are connected with Ved. à $y u$ - n. 'life, lifetime' and Av. àiiu- n. 'life, lifetime, time' or not. The close cognate of Ved. áyu- is attested in Lat. aevum n. 'period of time; past; future' (<PIt. ${ }^{*}$ aiwom n. 'period, age') and Lat. aetās $(t$-stem) f. 'age' (< PIt. ${ }^{*}$ aiwo-tât-s f. 'period, age'), cf. Pael. aetate gen. sg., Osc. aitatúm acc. sg. 'id.' (de Vaan 2008, 29).

10 Note that the Proto-Indo-European initial cluster ${ }^{*} d i$ - regularly yields Lat. $i$ - (and not $d i$-). Thus, the traditional explanation seems impossible for phonological (the original cluster ${ }^{*}$ di- is hardly accepted in a syllabic use ${ }^{*}$ dii- in Proto-Indo-European) and morphological reasons (PIE. ${ }^{*} d i-\bar{e} u-s$ 'sky-god', hence Lat. Iüppiter, gen. sg. Iovis 'id., was the animate agent noun of masculine gender; PIE. *di-uó- $m$ n. 'clear sky, day' and ${ }^{*} d i u-i-h_{1}$ du. n. 'day and night', hence Lat. divum 'sky' and diess 'day', were inanimate neuter nouns; all these words derive from the Proto-Indo-European root ${ }^{*} d e i$ - 'to shine', but their use was completely different). Moreover, it is extremely improbable that a new declension class was created on the basis of just one case (accusative sg.) of a single word. In other words, Piwowarczyk's view is hardly convincing from the typological and morphological point of view. 


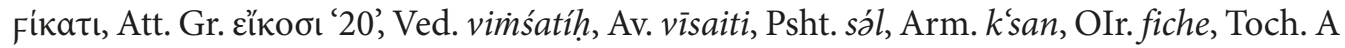
wiki, B ikam 'twenty.' ${ }^{11}$ Since all Latin numerals from four (Lat. quattuor) up to thousand (Lat. mille) did not decline, vigintī simply kept the shape of the nominative dual form.

The old dual forms were competing with the plural ones, supplanting them or coexisting as variants as in the case of the Latin forms frēnī, -ōrum and frēna, -ōrum 'reins, bridles, harnesses' (sg. frēnum $\mathrm{n}$.), see 6.1. above.

The dual forms ending in ${ }^{*}-\bar{i}\left(<\right.$ PIE. $\left.{ }^{*}-i h_{1}\right)$, especially dualia tantum, which were once present in Latin and had no singular forms, sometimes underwent collectivization and singularization. As a result of such an adaptation, the old dual forms had to be reconstructed morphologically and reinterpreted semantically. The collectivization and singularization of the old dual forms created the need to establish a new declension class. This was because innovative forms ending in $-i \bar{e} s\left(<{ }^{*}-i-e h_{1}-s\right)$ appeared in Latin, which represented the old dual forms transformed on the basis of the oblique case stem. These forms provided the impetus for the creation of the Latin fifth declension. The majority of the nouns of the Latin fifth declension are singularia tantum, which is an evident result of the collectivization and singularization of old dual forms.

In a few special cases the dual character of certain Latin nouns ending in -iēs may be documented through a detailed semantic analysis. Below I discuss several of the most evident examples.

8.1. The Latin word aciēs, -ièi f. 'sharp edge, sharp end, blade, sword' (figuratively 'sharpness') is commonly compared to the appellatives Lat. acia, -ae f. 'thread for sewing' (earlier *acŭia), acūmen, -inis n. 'blade, sharp end, sting' and acus, -us f. 'needle, spire, hairpin', as well as the verb acuō, -ere 'to whet, sharpen, cut to a point; spur on, provoke, incite' (< PIE. ${ }^{\star} h_{2} e k$ ' 'to be sharp'). The deverbal derivation is completely understandable in the majority of the cases but the word acus f. (u-stem) 'needle, spire, hairpin' may be treated as the basic form in Latin and Proto-Italic. Lat. aciēs f. 'blade (of a sword)' seems to represent the old dual form ${ }^{*} a c \bar{\imath}$ (gen. du. ${ }^{*} a c i \bar{e} s$, the stem ${ }^{*} a c i \bar{e}-$ also in other oblique cases) 'two blades (of a sword, knife, axe); a two-edged cutting tool' (<PIE. ${ }^{*} h_{2} e k^{\prime}-i h_{1}$ du., the stem in oblique cases $\left.{ }^{*} h_{2} e k-i, e h_{1}-\right)$. The dual character of the form can be easily confirmed by semantics: the Latin word aciēs f. refers to the two sharp edges of a sword, knife or battle-axe since in the ancient times swords, knives or battle-axes were two-edged, while Lat. acus $\mathrm{f}$. 'needle, spire, hairpin' is evidently singulative in character since a needle or pin has only one narrow blade. The pair acus vs. aciēs perfectly demonstrates the opposition between the old singular and the dual form (PIE. ${ }^{*} h_{2} e k^{\prime}-u s$ nom. sg. vs. PIE. ${ }^{*} h_{2} e k^{\prime}-i h_{1}$ nom. du.).

8.2. Lat. caesariēs, -iēi f. 'hair on the head, locks of hair' most likely represents the

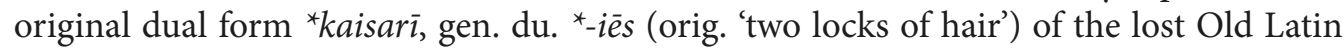
appellative ${ }^{*}$ caesar $\mathrm{m}$. (orig. 'lock of hair', cf. Ved. késara- m. 'hair, mane', késaravant-adj. 'having a mane'), preserved only in the cognomen Caesar (Pinault 1998; de Vaan 2008, 81 ), and later in the appellative caesar 'Roman ruler, emperor' created from the proper noun (Piwowarczyk 2013). In this case the original dual underwent collectivization, hence the evidently singular form and the evidently plural meaning of the word caesariēs, $-i \bar{e} i$ f. 'hair on the head, locks of hair.'

8.3. Lat. diēs, -iēi f. 'day' cannot be separated from OIr. die 'day', OW. did 'id., MW. $d y d d$, OBret. ded, Bret. deiz 'id.' < PC. *diiiī- or *diuiī- (Matasović 2009, 101). All these nouns

11 A wider range of comparative lexical material is presented in Pokorny $(1959,1177)$ and Beekes (2010, 381). Cf. also Lith. dvi dẽšimti 'two tens', dvidešimt 'twenty'. 
derive from the Italo-Celtic archetype ${ }^{*}$ diui $i e s$, which - in my opinion - goes back to an elliptic dual ${ }^{\star}$ diu-ih ${ }_{1}$ ('day and night', literally 'two days'), created on the basis of the Proto-Indo-European noun ${ }^{\star}$ diu-ó- $m$ n. 'clear sky, day', cf. Ved. divám n. 'clear sky, day', sudivám n. 'beautiful day', divédive (reduplicated loc. sg.) 'every day', Arm. tiv 'day', Lat. divum n. 'sky', sub divō 'under the open sky', biduum n. 'a period of two days' ( $<{ }^{*}$ duisdiuóm); OIr. indiu 'today' (< Goidelic Celtic *en-diuóm, lit. 'in this day'); W. heddiw 'today', Corn. hethew 'id.' (< Bryttonic Celtic ${ }^{\star}$ se-diuóm) (Pokorny 1959, 185; Matasović 2009, 101).

8.4. Lat. faciēs, -iēi f. 'figure, posture; face, appearance; head, snout; person; shape' is commonly treated as a deverbal derivative of the verb faciō 'to do, make, prepare, accomplish etc.' (de Vaan 2008, 198). This explanation is far from being certain. In my opinion, the Latin noun in question seems to represent the likely dual form ${ }^{*}$ faci nom. du. (gen. du. ${ }^{{ }^{*}}$ faciēs) with an elliptic meaning, originally perhaps 'skin and body' (vel sim.), ${ }^{12}$ which underwent singularization and transformed into an abstract noun faciēs f. 'figure, posture, appearance, shape' (also used with the concrete meaning 'face, head, snout'), as in the other discussed cases, on the basis of the forms of the oblique cases (nom. du. ${ }^{*}-i h_{1}$, obl. $\left.*_{-i e h}{ }^{-}\right)$.

8.5. The Latin words mäteria, -ae f. 'timber, tree trunk; building material; substance, ingredient, element' and māteriēs, -iēi f. (the same meaning) are evidently motivated by the appellative Lat. māter f. 'mother, tree trunk' (< PIE. ${ }^{*} m_{e} h_{2}$ ter- f.), cf. OInd. mātar- f., Gr. $\mu$ 'ं $\rceil \eta \rho$ f., Arm. mayr, Alb. motër f. 'sister', Toch. A mācar, B mācer 'mother' (de Vaan 2008,367 ). While the former word is the old collective with ${ }^{*}$-iieh ${ }_{2}$ (cf. Gr. Att. $\varphi \rho \bar{\alpha} \tau \rho i \bar{\alpha}$ f. 'fraternity, association, clan organisation', Toch. A pratri coll. 'brothers'; Witczak 2016), the latter seems to be derived from an old dual form ${ }^{*}$ mäteri f. du. 'two mothers' (< PIE. dial.

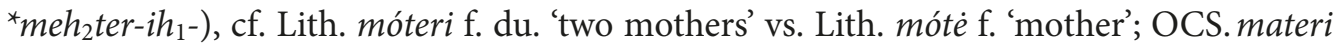
f. du. 'two mothers' vs. OCS. mati f. sg. 'mother'. The Latin word materia implies a multiple character of the material. If a thing was made of two ingredients (e. g., of copper and tin; timber and metal or flour and milk), then the use of the dual ${ }^{\star} m \bar{a} t e r \bar{i}$ du. 'two elements, two ingredients' was appropriate (in oblique cases mäteriē- $<{ }^{*} m e h_{2} t e r-i h_{1^{-}}$). In other words, the collective form mäteriēs f., created on the basis of the oblique case forms, was initially specifically dual. The form ending in -iēs referred to a substance made of two ingredients. It cannot be doubted that the Latin words mäteria and mäteriēs initially were not synonyms, but parallel forms with similar meanings.

8.6. Lat. seriēs, - $i \bar{e} i$ 'row, series, chain; succession of generations, clan, genealogy' is etymologically related to the verb Lat. serō, -ere 'to create, cause; bind, connect' (de Vaan 2008, 557) as well as Hitt. šariyezzi 3 sg. 'sews together, connects' (Kloekhorst 2008, 727), cf. also Hitt. šariya- n. 'chain, line.' The Latin noun can be traced back to the dual form ${ }^{*} \operatorname{ser} i \bar{i}\left(<\mathrm{PIE} .{ }^{*}{ }_{\text {ser-i }} h_{1^{-}}\right.$'two series, two chains, two clans'), which seems fully justified semantically. A chain (used as a necklace) consists of two parts wound around the neck on both sides. Similarly, each person has two parents from two different families, whence the collective form seriēs, based on the oblique cases ${ }^{*}{ }^{*} e r i \bar{e}-\left(<\right.$ PIE. $\left.{ }^{*}{ }^{*} e r-i e h_{1-}\right)$, which seems to reflect a dual form.

12 It cannot be excluded that Lat. faciēs f. 'figure, posture; face, appearance; head, snout; person; shape' (if from PIt. ' ${ }^{\star} w a k i \overline{)}$ ) is related to Hitt. tuekkan n. 'body', also tuekkaš c. 'body, person, self', Ved. tvák nom. f. (k-stem) 'skin, hide; leather bag', Skt. tvacam n. 'skin', Gr. бókoৎ n. 'shield (made of cow's hide)' (< PIE. ${ }^{*}$ tuekH- 'to cover', cf. Skt. tvacati 3 sg. 's/he covers'). 
The conducted semantic and etymological analysis has confirmed, as I believe, the originally dual character of the several selected Latin appellatives ending in -iēs (gen. sg. $-i \bar{e} i)$. It is beyond doubt that the form of the oblique cases served as the basis for the creation of the forms typical of the Latin fifth declension: the transformation of the old dual inflection ${ }^{*}-\bar{i}$ (with ${ }^{*}-i \bar{e}$ - in oblique cases) into a singular paradigm ${ }^{*}-i \bar{e} s,{ }^{*}-i \bar{e} i$ was a perfect basis for the creation of the Latin fifth declension already in the pre-literary period.

\section{Conclusions}

The detailed analysis of the Latin and Indo-European lexical data undertaken above has led to the following conclusions:

9.1. The oldest Indo-European languages had three number categories: the singular, the dual and the plural. The dual number was lost by most of the daughter languages and left some traces in a number of them. The dual has remained a productive category in Slovenian, Sorbian and in some Lithuanian dialects.

9.2. Classical Latin has very few traces of the old dual, limited to a handful of numerals (Lat. duo 'two', octō 'eight', vīgintī 'twenty'). Very few forms (especially the original dualia tantum) retained elements of the old dual inflection, cf. Lat. ambo, ambae, ambo m., f., n. 'both', duo, duae, duo m., f., n. 'two'.

9.3. The loss of the dual number in Latin, much like in the other Indo-European languages, caused pluralization, collectivization or singularization of the dual forms, i. e., their identification with either singular or plural forms.

9.4. The Latin fifth declension, which is most likely a pre-literary innovation, seems to be to a large extent a remnant of the old dual inflection.

9.5. The Proto-Latin dual forms ending in ${ }^{*}-\bar{e}\left(<\right.$ PIE. $\left.{ }^{*}-e h_{1}\right)$ were transformed by way of regular morphological processes into singulative forms in $-\bar{e} s$. Forms of this kind were later included in the new fifth declension.

9.6. The Proto-Latin dual forms ending in ${ }^{*}-\bar{i}\left(<\right.$ PIE. $\left.{ }^{*}-i h_{1}\right)$, especially dualia tantum of the type viginti 'twenty' (originally 'two tens'), were transformed into singulative forms in -iess. The change observed in Latin made use of and adapted as a standard the Proto-Indo-European suffix ${ }^{*}$-ieh $1^{-}$, which must have functioned in the oblique cases as the full grade of the dual suffix ${ }^{*}-i h_{1}$. Abstract nouns in -iess, which appear to be reflective of the dual forms in ${ }^{*}-\bar{i}$, were included in the Latin fifth declension, too.

9.7. The dual hypothesis provides a much better explanation for the early development of the Latin fifth declension than any of the other problematic (and redundant) solutions proposed thus far (e. g., Pedersen 1926; Mayrhofer 1986; Schrijver 1991; Klingenschmidt 1992; Piwowarczyk 2016; 2017; 2019).

\section{Abbreviations}

Alb. - Albanian; Arc. - Arcadian; Arm. - Armenian; Att. - Attic; Av. — Avestan; Bret. - Breton; c. - commune (gender); Corn. - Cornish; Cz. - Czech; Dor. - Doric; du. — dual; Hitt. - Hittite; Hom. - Homeric Greek; Lith. - Lithuanian; mid. — middle; MW. - Middle Welsh; OBret. - Old Breton; OCS. — Old Church Slavic; OE. — Old English; OInd. — Old Indic; OIr. — Old Irish; OLat. — Old Latin; Osc. - Oscan; OW. - Old Welsh; Pael. — Paelignian; PC. - Proto-Celtic; PGr. - Proto-Greek; PIE. - Proto-Indo-European; PIr. — Proto-Iranian; PIt. — Proto-Italic; Pol. — Polish; Psht. - Pashto; 
PSl. - Proto-Slavic; Skt. - Sanskrit; soc. - sociative; Toch. A - Tocharian A (or East Tocharian);

Toch. B - Tocharian B (or West Tocharian); Umbr. — Umbrian; Ved. — Vedic; W. — Welsh.

\section{References}

Adams D. Q. The Dual in Indo-European and Tocharian. Tocharian and Indo-European Studies 1991, 5, $11-44$.

Beekes R. Etymological Dictionary of Greek. Leiden - Boston, Brill, 2010.

Beekes R.S.P. The Origins of the Indo-European Nominal Inflection. Innsbruck, Institut für Sprachwissenschaft der Universität Innsbruck, 1985.

Beekes R.S.P. Comparative Indo-European Linguistics. An Introduction. Revised and corrected by M.de Vaan. Amsterdam - Philadelphia, John Benjamins Publishing Company, 2011.

Blažek V. Numerals. Comparative-Etymological Analysis of Numeral Systems and Their Implications. Brno, Masarykova Univerzita v Brně, 1999.

Buck, C. D. Comparative Grammar of Greek and Latin. London, Bristol Classical Press, 2009 (first edition: Chicago, University of Chicago Press, 1933).

Clackson J. Indo-European Linguistics. An Introduction. Cambridge, Cambridge University Press, 2007.

Dostal A. Vývoj duálu v slovanských jazycích, zvláště v polštině. Praha, Nakladatelství Československé Akademie Věd, 1954.

Fero B. Studi sul duale in miceneo, nella poesia omerica e nel teatro attico del V secolo. Variazioni morfologiche, dialettali, stilistiche. Bologna, Università di Bologna, 2013.

Fritz M. Der Dual im Indogermanischen. Genealogischer und typologischer Vergleich einer grammatischen Kategorie im Wandel. Heidelberg, Winter, 2011.

Habrajska G., Rychło M., Witczak K. T. Collective Nouns Denoting Trees in the Scandinavian Languages. Scandinavian Philology 2020, 18 (2), 261-283.

Hierche H. Lemploi du duel dans les formules homériques. Lyon, Institut d'études indo-européennes de l'Université Jean Moulin, 1987.

Klingenschmitt G. Die lateinische Nominalflexion, in: O. Panagl, T. Krisch (eds.) Latein und Indogermanisch. Innsbruck, Institut für Sprachwissenschaft der Universität Innsbruck, 1992, 89-135.

Kloekhorst A. Etymological Dictionary of the Hittite Inherited Lexicon. Leiden - Boston, Brill, 2008.

Kortlandt F. A Note on the Tocharian Dual. Tocharian and Indo-European Studies 1991, 5, 5-10.

Leumann M. Lateinische Laut- und Formenlehre. München, Beck, 1977.

Malzahn M. Der nominale Dual im Rgveda. Wien, Universität Wien, 1999.

Malzahn M. Toch. B ñaktene "Gotterpaar" und Verwandtes. Tocharian and Indo-European Studies 2000, 9, $45-52$.

Mańczak W. Proto-indo-européen ${ }^{\star} a m b h o ̄(u),{ }^{\star} a m b h i$, in: L. Isebaert (ed.) Studia etymologica Indoeuropaea memoriae A. J. van Windekens dicata. Leuven, Peeters, 1991, 179-186.

Matasović R. Etymological Dictionary of Proto-Celtic. Leiden - Boston, Brill, 2008.

Mayrhofer M. Indogermanische Grammatik, vol. 1, 2. Heidelberg, Carl Winter, 1986.

Meier-Brügger M. Indogermanische Sprachwissenschaft. Berlin - New York, Walter de Gruyter, 2000.

Meiser G. Historische Laut- und Formenlehre der lateinischen Sprache. Darmstadt, Wissenschaftliche Buchgesellschaft, 2010.

Pedersen H. La cinquième déclinaison latine. Copenhagen, Høst, 1926.

Pinault G.-J. Analyse de latin caesaries, in: B. Bureau, C. Nicolas (eds.) Moussyllanea. Mélanges de linguistique et de littérature anciennes offerts à Claude Moussy. Louvain - Paris, Peeters, 1998, 15-30.

Piwowarczyk D. R. The Story of Caesar revisited. Studia Etymologica Cracoviensia 2013, 18, 105-110.

Piwowarczyk D. R. The Origin of the Latin -iēs/-ia inflection. Historische Sprachforschung 2016, 129 (1), $108-123$.

Piwowarczyk D. R. The Magnificent Five - the Latin Fifth declension revisited, in: M. Németh, B. Podolak, M. Urban (eds) Essays in the History of Language and Linguistics dedicated to Marek Stachowski on the occasion of his $60^{\text {th }}$ birthday. Kraków, Księgarnia Akademicka, 2017, 511-523.

Piwowarczyk D. R. The Latin Fifth Declension and the Baltic -ē-stem. Baltistica 2017, 52 (2), 247-263. [bis]

Piwowarczyk D. R. The Latin-iēs/-iā Inflection - Synchronic Evidence and Diachronic Origin. Kraków, Jagellonian University Press, 2019.

Pokorny J. Indogermanisches etymologisches Wörterbuch. Bern — München, Francke Verlag, 1959. 
Pultrová L. The Latin Deverbative Nouns and Adjectives. Prague, Karolinum Press, 2011.

Rieken E. Der Wechsel -a-/-i- in der Stammbildung des hethitischen Nomens. Historische Sprachforschung 1994, 107 (1), 42-53.

Rieken E. Untersuchungen zur nominalen Stammbildung des Hethitischen. Wiesbaden, Harrassowitz Verlag, 1999.

Schrijver P. The Reflexes of the Proto-Indo-European Laryngeals in Latin. Amsterdam - Atlanta, Rodopi, 1991.

Sihler A.L. New Comparative Grammar of Greek and Latin. New York - Oxford, Oxford University Press, 1995.

Stang C. Vergleichende Grammatik der baltischen Sprachen. Oslo, Universitetsforlaget, 1966.

Tjasa J. The Dual in Slovene Dialects. Bochum, Universitätsverlag Brockmeyer, 2008.

Untermann J. Wörterbuch des Oskisch-Umbrischen. Heidelberg, Winter, 2000.

de Vaan M. Etymological Dictionary of Latin and the Other Italic Languages. Leiden - Boston, Brill, 2008.

Wackernagel J. Altindische Grammatik, vol. 2, 1. Göttingen, Vandenhoeck \& Ruprecht, 1957.

Weiss M. Outline of the Historical and Comparative Grammar of Latin. Ann Arbor - New York, Beech Stave Press, 2009.

Weiss M. Cosmologia Italica, in: A. Ancillotti, A. Calderini, R. Massarelli (eds.) Forme e strutture della religione nell'Italia mediana antica / Forms and Structures of Religion in Ancient Italy. III Convegno Internazionale dell'Istituto di Ricerche e Documentazione sugli Antichi Umbri. 21-25 settembre 2011. Roma, L’Erma di Bretschneider, 2017, 661-667.

Witczak K. T. Dioscuri in the Mycenaean Times. Do-so-mo 2011, 9, 57-68.

Witczak K. T. Konsekwencje zaniku liczby podwójnej w języku łacińskim. Głos w sprawie dualnej genezy piątej deklinacji łacińskiej. Roczniki Humanistyczne 2015, 53 (6), 101-120.

Witczak K. T. Gaulish suiorebe ‘with two sisters'. Lingua Posnaniensis 2015, 57 (2), 59-62. [bis]

Witczak K. T. Nierozpoznane collectivum w językach tocharskich: toch. A pratri 'bracia'. Roczniki Humanistyczne 2016, 64 (9), 119-133.

Witczak K. T. Pozostałości liczby podwójnej w języku łacińskim epoki archaicznej. Roczniki Humanistyczne 2017, 65 (3), 37-58.

Witczak K. T. Łacińskie lōrum w świetle etymologii. LingVaria 2017, 12 (2), 185-196. [bis]

Witczak K.T. O kilku możliwych śladach duale tantum w językach indoeuropejskich. LingVaria 2018, 13 (2), 47-58.

Witczak K. T. Liczba podwójna w archaicznej poezji rzymskiej. Roczniki Humanistyczne 2019, 67 (3), 107123.

Witczak K. T. Rodilniške oblike na -erum in -us v arhaični latinščini. Keria: Studia Latina et Graeca 2021, $23(1), 5-18$. 